DOLLARD, J., DOOB, L. W., MILLER, N E.. MOWRER, O. H., \& SEARS, R. R. Frustration and aggression. New Haven: Yale University Press, 1939.

GINSBERG, B., \& ALLEE, W. C. Some effects of conditioning on social dominance and subordination in inbred strains of mice. Physiological Zoology. $1942,15,485-506$

SCOTT, J. P., \& FREDERICKSON, E. The causes of fighting in mice and rats. Pbysiological Zoology, 1951, 24, 273-309.

STEVENSON, J. A. F., \& RIXON, R. H. Environmental temperature and deprivation of food and water on the spontaneous activity of rats. Yale Journal of Biology \& Medicine, 1957, 29, 575-584.

ULRICH, R. E., \& AZRIN, N. H. Reflexive fighting in response to aversive stimulation. Journal of the Experimental Analysis of Behavior, 1962, 5, 511-520. WALLIS, D. I. Aggressive behavior in the ant (Formica fusca). Animal Behaviour, $1962,10,267-274$

WELCH, A. S. Isolation, reactivity, and aggression: Possible involvement of brain catechol- and indoleamines. Paper presented at AAAS meeting, Dallas, 1968 .

WINER, B. J. Statistical principles in experimental design. New York: McGraw-Hill, 1962.

\title{
Effect of a signal previously paired with free food on operant response
} \section{rate in pigeons*}

\author{
G. WILLIAM FARTHING \\ University of Maine, Orono, Maine 04473
}

In Phase 1, food was presented independently of the birds'behavior. In one group, the food was paired with an auditory CS; in the other group, CS and food occurred randomly. In $\mathrm{Ph}$ ase 2 , the birds were trained to peck a key for variable-interval food reinforcement, with $\mathrm{CS}$ off. Then, following additional Phase 1 training, they were tested with CSs presented during operant extinction. For both keypecking and a photocell measure of activity near the speaker, the CS preduced changes in behavior which, when measured independently of the direction of change, were significantly greater in the paired group than in the random group.

Rescorla \& Solomon (1967) have discussed the importance of studying interactions between classical and operant conditioning by superimposing classical CSs on operant response baselines. In an experiment which involved positive reinforcement during both the classical and operant conditioning phases, Estes (1948) gave rats several tone-food pairings, then trained them to press a lever for food reinforcement, and finally presented the tone occasionally during operant extinction; operant response rates increased during tone presentations. The present study was an attempt to

*This research was supported by NIMH Grant MH-18290 and a University of Maine COE Fund grant to the author, who thanks John Arthur, Steve Cohen, Charles Hayden. Charles Kowal, Tom Nelson, and Mike Opuda for assistance in various phases of this project. replicate Estes' (1948) experiment, using pigeons as Ss.

\section{SUBJECTS AND APPARATUS}

Fourteen experimentally naive Silver King pigeons (5-8 years old) were maintained at $75 \%$ of their free-feeding body weights. An operant conditioning test chamber was equipped with a response key, houselight, and feeder. A 6-cm-diam speaker was mounted behind perforations in the upper left corner of the intelligence panel, about $14 \mathrm{~cm}$ from the response key. A photocell was mounted about $3 \mathrm{~cm}$ from the lower left edge of the speaker, and light was projected on the photocell through an opening in an aluminum box that was suspended $15 \mathrm{~cm}$ in front of the speaker. External sounds were masked by a white noise in the room, which produced a noise level of about
$85 \mathrm{~dB}$ inside the chamber. The CS was a high-frequency (approximately $80 \mathrm{~Hz}$ ) train of clicks, which raised the noise level to about $93 \mathrm{~dB}$. Food reinforcers consisted of $3 \mathrm{sec}$ of access to mixed grain. Automatic programming and recording equipment were in an adjacent room. \section{PROCEDURE}

In Phase 1, all Ss were given six sessions in which a 10 -sec CS and a food reinforcer were present 60 times each, independently of the birds' behavior. In the paired group $(\mathrm{N}=8)$, food was always delivered immediately following the CS, with the CS occurring on a variable-interval (VI) schedule with a mean of 60 sec (range: $30-90 \mathrm{sec})$. In the random group $(N=6)$, the $C S$ and food were presented on independent VI 60-sec schedules. In Phase 2 , the birds were trained to peck a red response key by the method of successive approximations and were then given six 60-reinforcement sessions, with pecks reinforced on a VI 30-sec schedule during the first session and on a VI 60-sec schedule during the last five sessions. No CSs were presented during Phase 2. In Phase 3, all birds were given two more sessions identical to Phase 1. Throughout Phases 1 and 3 , photocell responses were recorded every time the photocell beam was broken during the 10 -sec $\mathrm{CS}$ intervals and also during $10-\mathrm{sec}$ intervals immediately preceding each CS presentation. The response key was covered by a cardboard patch during Phases 1 and 3 .

On the day after the last Phase 3 session, each bird was given a 10-reinforcement warm-up of Phase 2 training, followed by a $2-h$ test session during which no reinforcers were delivered (extinction). In the test session, CS was presented for 60 $30-\mathrm{sec}$ trials, with from 60 to $120 \mathrm{sec}$ between trials. The first test trial occurred after 60 to $120 \mathrm{sec}$ of extinction. Photocell and keypeck responses were recorded during CS intervals and also during $30-\mathrm{sec}$ intervals immediately preceding each CS presentation.

\section{RESULTS}

Peck- and photocell-response data were transformed into two different ratios which express the relative difference in response totals during pre-CS intervals (A) vs CS intervals (B). The directional difference ratio equals $B$ divided by $A+B$; this ratio can range from 0 to 1.0 , with values greater than 0.5 indicating more responding in CS and values below 0.5 indicating less responding in $\mathrm{CS}$, as compared to the pre-CS interval. The nondirectional difference ratio equals $A$ or $B$, whichever is smaller, divided by $\mathrm{A}+\mathrm{B}$; this ratio can range from 0 
to 0.5 , with lower values indicating a greater relative change in response frequency from pre-CS intervals to CS intervals, independently of the direction of the change.

In the last session of Phase 1, nondirectional photocell response ratios averaged .171 for the paired group and .368 for the random group $(t=2.23, p<.025$, by a one-tailed test). The groups did not differ significantly in directional photocell ratios: In the paired group $(\mathrm{N}=8)$, this ratio was below 0.40 for six birds and above 0.60 for one bird (above 0.50 for two birds); in the random group $(N=6)$, it was below 0.40 in one bird and above 0.60 in one bird (above 0.50 in two birds). The overall median preCS photocell response rate in this session was $6.7 / \mathrm{min}$; the groups did not differ significantly on this measure. Photocell response data for the last session of Phase 3 were essentially the same as for the last session of Phase 1 (nondirectional ratios of .140 and $.370, t=3.63$, $\mathrm{p}<.01)$.

Observation of the birds during Phases 1 and 3 revealed that their typical behavior consisted of pacing back and forth in front of the intelligence panel. In the random birds, there was no obvious change in behavior when the CS came on. Six of the paired birds typically reduced their pacing during CS and oriented toward, and sometimes pecked near, the feeder opening. However, two of the paired birds typically oriented toward the speaker during CS. ${ }^{1}$

Test data were divided into five blocks of 12 trials each. In the first block, nondirectional peck ratios averaged .314 for the paired group and .462 for the random group $(t=2.18$, $\mathrm{p}<.025$ ); however, although the differences were in the same direction, the groups did not differ reliably on this measure in the other test blocks or for the test as a whole. The groups did not differ significantly on directional peck ratios for the test as a whole or for any of the separate test blocks. For the first test block, in the paired group $(\mathrm{N}=8)$ the directional peck ratio was below 0.40 for four birds and above 0.60 for none (three birds had ratios above 0.50 ); in the random group all of the ratios were between 0.40 and 0.60 (three birds had ratios above, and three below, 0.50 ). For the test as a whole, the directional peck ratio was below 0.50 in seven of eight paired birds and five of six random birds. ${ }^{2}$ The overall median number of preCS pecks was 160 in the first block and 470 in the whole test; the groups did not differ significantly on either of these measures.

For the test as a whole, nondirectional photocell response ratios averaged .344 for the paired group and .477 for the random group $(t=2.47, p<.025)$. The groups did not differ significantly in directional photocell ratios for the test as a whole: In the paired group $(N=8)$, this ratio was below 0.40 for one bird and above 0.60 for four birds (above 0.50 for five birds); in the random group $(N=6)$, this ratio was below 0.40 for one bird and above 0.60 for none (above 0.50 for two birds). The groups did not differ reliably on either type of photocell response ratio during any of the individual test blocks, at least partly due to the low frequency of such responses in many of the birds. The overall median number of preCS photocell responses was 16 for the first block and 65 for the whole test; the groups did not differ significantly on either of these measures. For the paired group, correlations between directional peck ratios and directional photocell ratios were not significant, either for the first test block or for the test as a whole.

\section{DISCUSSION}

The present experiment fails to replicate Estes's (1948) results. The CS increased barpress rates in Estes's rats, whereas in the first test block, CS did not produce any consistent incremental or decremental effects on the pigeons' peck rates. There were several differences in procedural details between the two experiments, so it is not known whether the different results were due to species differences or to procedural differences.

The fact that, over the test as a whole, most of the birds in both groups pecked less during CS than during pre-CS intervals can probably be explained simply as a generalization decrement, since prior peck training had been given only with the CS off.

The failure to find a reliable difference between the groups' directional peck ratios cannot be attributed to a failure of the paired birds to learn about the CS-food relationship, since during the CS-food training in Phases 1 and 3 , there were significant differences between the groups' nondirectional photocell response ratios, and this difference was maintained during the test session.

Longo et al (1964) obtained significant increases in pigeons stabilimeter activity during $\mathrm{CS}$ when a 10-sec CS was paired with food independently of the birds' behavior. They suggested that one possible interpretation of their results was that the birds learned to make "superstitious" operant responses (Skinner, 1948) during CS, as a result of accidental contingencies between responses and reinforcers. Photocell response data and observations of the birds' behavior suggest that the birds in the paired group of the present experiment learned "superstitious" operant responses during CS-food training in Phases 1 and 3 . In some cases, these "superstitious" responses may have been compatible, and in other cases, incompatible, with keypecking. (A significant negative correlation between directional peck and directional photocell response ratios would support this hypothesis, but the fact that this correlation was not significant does not disprove the hypothesis, since the photocell did not detect all of the possible responses that would be incompatible with key pecking.) Thus, during the first few test trials, the CS did not produce any consistent incremental or decremental effects on keypecking, but it produced significantly greater changes in peck rates, measured nondirectionally, in the paired group than in the random group. Any attempt to test hypotheses about the motivational effect of classical CSs on operant responding is likely to be complicated by the Ss' learning to make "superstitious" operant responses during $\mathrm{CS}$, which may be incompatible with the operant response being measured by the $E$.

\section{REFERENCES}

ESTES, $W$. $K$. Discriminative conditioning. II. Effects of a Pavlovian conditioned stimulus upon a subsequently established operant response. Journal of Experimental Psychology, 1948, 38, 173-177.

LONGO, N.. KLEMPAY, S \& \& BITTERMAN, M. E. Classical appetitive conditioning in the pigeon. Psychonomic Science, 1964, 1, 19-20.

RESCORLA, R. A., \& SOLOMON, R. L. Two-process learning theory: Relationships between Pavlovian conditioning and instrumental learning. Psychological Review, 1967, 74, 151-182 SKINNER, B. F. "Superstition" in the pigeon. Journal of Experimental Psychology, 1948, 38, 168-172.

$$
\text { NOTES }
$$

1. In an unpublished experiment, two of eight pigeons were observed frequently pecking at the speaker during a $1,000-\mathrm{Hz}$ tone which was paired with free food on a VI 30-sec schedule, but they rarely pecked the speaker during a $4,000-\mathrm{Hz}$ tone which was not paired with food. In the present study, in hopes of obtaining more objective evidence for this apparent autoshaping to an auditory stimulus, a large opaque perforated response key was mounted behind a $5-\mathrm{cm}$ opening in the intelligence panel in front of the speaker. During the first two sessions of Phase 1, one paired bird made 190 pecks at the speaker during CS intervals, but only 64 during preCS intervals; this bird also made 20 pecks at the speaker during CS intervals in the test, but none during preCS intervals. Other birds made few or no pecks at the speaker during training and none during the test. Autoshaping to an auditory stimulus may be possible, but the conditions under which it can be reliably produced have not yet been determined.

2. In a pilot study involving paired training and testing conditions similar to the present study, all six birds had directional peck ratios below 0.5 for the test as a whole. 